ORIENTAL JOURNAL OF
ISSN: 0974-6471
April 2016,
COMPUTER SCIENCE \& TECHNOLOGY

\title{
A Study on Usage of E-Commerce through Cell Phones by College Students
}

\author{
J TAMIZHKUMARAN ${ }^{1 *}$, SABAR RANJANMAYEE ${ }^{2}$, \\ P MANESH KUMAR $^{3}$ and P RAMAJAYAM ${ }^{4}$ \\ ${ }^{1}$ Ph.D Scholar, ${ }^{2}$ Post Graduate Scholar, \\ Department of Veterinary and A.H. Extension Education, \\ ${ }^{3}$ Ph.D Scholar, Department of Animal Biotechnology \\ ${ }^{4}$ Post Graduate Scholar, Department of Animal Genetics and Breeding \\ Madras veterinary college, Vepery, Chennai 600 007, India. \\ *Corresponding author E-mail: docjtk@ gmail.com \\ http://dx.doi.org/10.13005/ojcst/901.09
}

(Received: January 23, 2016; Accepted: March 02, 2016)

\begin{abstract}
A study was conducted among the veterinary college students to ascertain the usage pattern of e-commerce in mobile application. A total of 120 students were interviewed personally with a semi structured interview schedule designed for the study. The study revealed that majority of the respondent ( $85 \%$ ) preferred android based phones, the main purpose for e-commerce usage through cell phones were used for recharging cell phones (78.3\%), booking tickets $(53.3 \%)$, paying the bills $(35 \%)$, online shopping $(28.3 \%)$, money transfer $(05.8 \%)$ and hotel booking $(5 \%)$. The major e-commerce activity was carried out using debit/ ATM cards $(80 \%)$, internet banking $(35 \%)$ and mobile banking (11.6\%). The popular apps preferred by the respondents were Paytm $(71.6 \%)$, Red Bus (44.1\%), Book My show (43.3\%), Ticket New (39.1\%) and Irctc (32.5\%). It is clear from the study that college students are interested in e-commerce usage through mobile applications and in coming years the trend of e-commerce usage will surely take a turn around.
\end{abstract}

Keywords: E-commerce, mobile banking, college students, cell phone.

\section{INTRODUCTION}

Electronic commerce or E-commerce consists primarily of the distributing, buying, selling, marketing, and servicing of products or services over electronic systems such as the Internet and other computer networks. In the broad meaning electronic commerce is a means of conducting business using one of many electronic methods, usually involving internet, computers or both.
E-Commerce is not about the technology itself, it is about doing business using the technology (Guan, 2008). E-commerce is changing the shape and the concepts of business. New technologies that could significantly bring paradigm shift in the e-commerce. In the recent years innovative technologies emerge the E-commerce market is gradually changing and getting more and more attractive for consumers by offering them new advantages and unmatched conveniences. (Thomas and Jose, 2015) 
It is an electronic business application and involves electronic fund transfer, supply chain management, online transaction processing, e-marketing, corporate purchasing, value chain integrations etc. With the onset of information technology the way we do business has changed. It replaced from paper cheque or money to electronic payment system, from paper or postal invoice to electronic invoice and form traditional commerce to electronic commerce etc (Achugbue, 2014). Today the internet and E-commerce are daily routine in our life. It is no longer a device to be used only by highly wealthy and technologically advanced people. Now it is very popular today with all kinds of people from rich to poor, from businessmen to employees, from scientists to school going students (Thomas and Jose, 2015).

With mobile apps being developed by most e-Commerce websites, smart phones are increasingly replacing PCs for online shopping. In 2013 , only $10 \%$ of the mobile users used smart phones, and only $5 \%$ of the e-Commerce transactions were made through a mobile device. This figure has more than doubled, and more than $13 \%$ of all e-Commerce transactions today happen via mobile. According to some industry players, over $50 \%$ of the orders are being placed through mobile apps, which is not only leading to substantial customer acquisition but also building customer loyalty for various brands. However, most mobile transactions so far are for entertainment, such as booking movie tickets and music downloads. This trend will change soon with more and more merchandise being ordered online (IAMAI, 2014).

The number of mobile subscribers in India jumped from 261 million in 2007-2008 to 910 million in 2013-2014. Along with telephony, internet penetration is soaring in rural and urban India. Moreover, the number of rural internet users is growing by $58 \%$ annually. Increases in the number of smart phones and 3G subscriptions are further driving this growth. Indeed, the number of smart phone users is expected to grow at a CAGR $91 \%$ from 2012 through 2016, jumping from 29 million to 382 million (pwc,2015).

Flipkart.com and Myntra.com were the most preferred choice of online retailers mentioned by the students to shop from the online stores. Tickets, electronic goods accessories, apparels, books, electronic goods, footwear, instant recharge of cell phone, gifting items, were the major categories of products / services bought by most of the students. Cash on delivery was the most preferred mode of payment stated by the students while doing online shopping (Jadhav and Khanna,2016).

In the study done in India by P. UshaVaidehi (2014), it was revealed that male students are more interested in purchasing goods online when compared to female students. This study exhibits that the Factors such as shopping online saves time, availability of the product for less price, promotions that E- Retailers are providing, ease in payment are the motivating drives to encourage students to shop more online. However both male \& female respondents preferred to purchase goods online and they were more interested to buy apparels, electronic goods and books through online. Khare and Rakesh (2011), in their study conducted in India on "Antecedents of Online Shopping Behavior in India: An Examination," found that Indian students' intention to purchase online is influenced by utilitarian value, attitude toward online shopping, availability of information, and hedonic values. Satisfaction, trust and commitment were found to have significant impact on student loyalty toward online shopping, in the study carried out in Indonesia by Pratminingsih et al. (2013).

According to the Statista website report it is estimated that 75 per cent of the Internet users in India are between the age group of 15 to 34 years of age, which is a clear indicator that the mobile apps and mobile banking is done by the graduates. Keeping this in mind the study was carried out to assess the Usage of e-commerce through Cell phones by college students.

\section{MATERIALS AND METHODS}

A survey was carried out among the under graduate, Post graduate and doctorates students of Madras Veterinary college and to assess the usage of mobile applications with respect to e-commerce. Madras veterinary college 
was selected for the reason it has a cosmopolitan environment representing students from various parts of the country. A semi structured interview schedule was designed for the study. A total of 120 students were randomly selected and the data was collected through personal interview. The results were analyzed based on the response. The data was analyzed using SPSS 16.0

\section{RESULTS AND DISCUSSION}

The study revealed that majority $(57.5$ per cent) were in the range of $18-22$ yrs of age, followed by 42.5 per cent who belonged to age group of $23-$ 28 years. The respondents were belonging to three categories out of which three-fourth (61.6 per cent) were under graduate students followed by $28.4 \mathrm{per}$ cent of post graduate students and 10 per cent belonged to doctorate categories. The e-commerce activity was observed the most in case of the post graduate students and the doctorate students compared to that of the under graduates. This might be due to the reason that the post graduate and doctorate students were receiving a stipend during their study and their much experienced in the using the cell phone.

Table 1: Profile of the college students $\mathrm{N}=120$

\begin{tabular}{llll}
\hline S.No & Particulars & Frequency & Percentage \\
\hline Age (in yrs) & & & \\
1. & 18 to 22 & 69 & 57.5 \\
2. & 23 to 28 & 51 & 42.5 \\
Type of Cell phone used & & \\
1. & Android phones & 102 & 85.0 \\
2. & Windows & 12 & 10.0 \\
3. & Basic model Phones & 04 & 03.4 \\
4. & los & 02 & 01.6 \\
Graduation & & \\
1. & Under graduates & 74 & 61.6 \\
2. & Post graduates & 34 & 28.4 \\
3. & Doctorates & 12 & 10.0 \\
Payment * & & & \\
1. & Mobile banking & 14 & 11.6 \\
2. & Internet banking & 42 & 35.0 \\
3. & Debit card/ ATM card & 96 & 80.0 \\
\hline
\end{tabular}

${ }^{*}$ multiple response not to total

Table 2: Purpose for E-commerce usage $\mathrm{N}=120$ *

\section{S.No Purpose Frequency Percentage}

\begin{tabular}{llll}
\hline 1. & Recharge & 94 & 78.3 \\
2. & Ticket booking & 64 & 53.3 \\
3. & Bill payments & 45 & 35.0 \\
4. & Online shopping & 34 & 28.3 \\
5. & Money transfer & 07 & 05.8 \\
6. & Hotel booking & 06 & 05.0 \\
\hline
\end{tabular}

*multiple response not to total
Most of the college student around 85 per cent preferred android phones followed by 10 per cent who used windows based phones and a meager 3.4 per cent used basic phones and only two respondents $(01.6 \%)$ used apple phones (Table.1).

Though majority $(96.6 \%)$ of the college students owned a smart phone, the major e-commerce activity was carried out using debit/ ATM cards ( 80 per cent) followed by 35 per cent 
Table 3: Different Apps involved in E-commerce usage $\mathrm{N}=120^{*}$

\begin{tabular}{|c|c|c|c|}
\hline S.No & Apps used & Frequency & Percentage \\
\hline \multicolumn{4}{|c|}{ Online shopping apps } \\
\hline 1. & Paytm & 86 & 71.6 \\
\hline 2. & Flipkart & 16 & 13.3 \\
\hline 3. & Myntra & 06 & 05.0 \\
\hline 4. & Snapdeal & 04 & 03.3 \\
\hline 5. & Amazon & 03 & 02.5 \\
\hline 6. & eBay & 02 & 01.6 \\
\hline 7. & Jabong & 02 & 01.6 \\
\hline \multicolumn{4}{|c|}{ Mobile recharging apps } \\
\hline 1. & My airtel & 35 & 29.1 \\
\hline 2. & My idea & 08 & 06.6 \\
\hline 3. & My bsnl & 03 & 02.5 \\
\hline \multicolumn{4}{|c|}{ Travel booking apps } \\
\hline 1. & Red bus & 53 & 44.1 \\
\hline 2. & Irctc & 39 & 32.5 \\
\hline 3. & Make my trip & 08 & 06.6 \\
\hline \multicolumn{4}{|c|}{ Movie booking apps } \\
\hline 1. & Book my show & 52 & 43.3 \\
\hline 2. & Ticket new & 47 & 39.1 \\
\hline 3. & Theatre apps & 37 & 30.8 \\
\hline \multicolumn{4}{|c|}{ Mobile banking apps } \\
\hline 1. & V-Mobile & 03 & 02.5 \\
\hline 2. & U- Mobile & 02 & 01.6 \\
\hline 3. & State Bank anywhere & 02 & 01.6 \\
\hline
\end{tabular}

*multiple response not to total

who used internet banking and only 11.6 per cent of the respondents were using mobile banking facility in their smart phones (Table.1).

\section{Purpose for using E-commerce in cell phones}

The college students felt shopping through mobile saved a lot of time for them, the college students used the cell phones for various purposes with respect to e-commerce like recharging for internet and top-ups for their cell phones (78.3\%), booking tickets for movie/bus/train/flights (53.3\%), paying the bills for the electricity and landline phones (35\%), online shopping of goods(28.3\%), money transfer to their friends and family members $(05.8 \%)$ and for five per cent used for booking rooms in hotel (Table.2).
The purposes for which the e-commerce was used through cell phones are summarized and given here; the recharges were mainly done for their own cell phones or their friend's cell phone or for their family members. The recharges were mainly for top-ups, extend validity, rate cutters and for internet packs. With respect to ticket booking, mostly it was movie tickets followed by bus tickets, Train tickets and only two respondents used for booking flight tickets. Online shopping was done for purchasing shoes, computer and mobile accessories, books etc., though majority did only window shopping rather than purchasing the products. Seven respondents used mobile banking to transfer amount to their family members' bank account. 


\section{Different Apps used for E-commerce in Cell phones}

Though there are many apps in android and los, there were few apps which were more preferred by the college students for the purpose of E-commerce. The results of different apps used by the college students for the purpose of E-commerce in this present study is discussed here

The apps used by the college students are grouped into five categories viz., Online shopping apps, mobile recharging apps, travel booking apps, movie booking apps and mobile booking apps.

Among the online shopping apps used for the e-commerce PAYTM was preferred by most $(71.6 \%)$ of the college students followed by Flipkart (13.3\%), Myntra (05\%), Snapdeal (3.3\%), Amazon (2.5\%), two respondents each used eBay and Jabong respectively (Table.3). The respondents who used these apps for E-commerce purpose alone were considered for the study, whereas others who used the apps to browse/ compare the rates of different products before buying them in market were not included as they did not use the app for E-commerce purpose. The study was in conscience with study conducted by Jadhav and Khanna (2016) who reported that Flipkart and Myntra were the most preferred online shopping sites.

Most of the respondents (71.6\%) preferred to recharge their cell phones through Paytm followed by few respondents who used the direct mobile charging apps like My Airtel (29.1\%), My Idea (6.6\%) and My Bsnl (2.5\%) for recharging the cell phone (Table.3).

Travel booking apps like Redbus (44.1\%), Irctc $(32.5 \%)$ and around seven percent of the respondents used Make my trip app for booking their travel tickets. The travel booking apps were used by almost 53 per cent of the respondents has many were from different states who have come to study in veterinary colleges in Chennai. Movie booking apps were the most popular apps among the college students, the most preferred apps was Book my show (43.3\%), followed by ticket new $(39.1 \%)$ and around one-fourth $(30.8 \%)$ of the respondents used the respective theatre apps for booking tickets (Table.3).

Mobile banking apps were used only by seven respondents out of which three respondents used V-mobile, two respondents each used State bank anywhere and U- mobile respectively. The mobile banking app was used for checking balance and mini statement. Around six per cent of the respondents used mobile banking for money transfer.

\section{CONCLUSION}

The study revealed that majority of the respondent preferred android based phones, the main purpose for e-commerce usage through cell phones were used for recharging cell phones, booking tickets, paying the bills , online shopping , money transfer and hotel booking. The respondents who did not use the e-commerce apps used them for comparing the rates before buying a product in the market. The major e-commerce activity was carried out using debit/ ATM cards, internet banking and mobile banking. The popular apps preferred by the respondents were Paytm, Red Bus, Book My show, Ticket New and Irctc. The usage of e-commerce was observed more among the Post graduate students compared to the under graduates. It is clear from the study that college students are interested in e-commerce usage through mobile applications and in coming years the trend of e-commerce usage will surely take a turn around.

\section{REFERENCES}

1. Achugbue, E. I. E-Business in Education:The Case of Delta State University. Handbook of Research on Demand-Driven Web Services: Theory, Technologies, and Applications: Theory, Technologies, and Applications, 356
(2014).

2. Guan, S. U. Roaming-Agent Protection for E-Commerce. Brunel University, UK (2008).

3. IAMAI, Internet and Mobile Association of India (IAMAI), CRISIL, Gartner, PwC 
analysis and industry experts (2014).

4. Jadhav, V., \& Khanna, M. Factors Influencing Online Buying Behavior of College Students: A Qualitative Analysis. The Qualitative Report, 21(1), 1-15 (2016).

5. Khare, A., \& Rakesh, S. Antecedents of online shopping behavior in India: An examination. Journal of Internet Commerce, 10: 227-244 (2011).

6. PWC, Price Waterhouse Coopers India Report "e-Commerce in India Accelerating growth".http://www.pwc.in/assets/pdfs/ publications/2015/ecommerce-in-indiaaccelerating-growth.pdf accessed on
10.01.2016 (2015).

7. Pratminingsih, S. A., Lipuringtyas, C., \& Rimenta, T. Factors influencing customer loyalty toward online shopping. International Journal of Trade, Economics and Finance, 4(3): 104-110 (2013).

8. Thomas, S., \& Jose, P. V. Recent Trends in E-Commerce. International Research Journal of Engineering and Technology (IRJET) e-ISSN: 2395-0056 Volume: 02 Issue: 06 I Sep-2015 www.irjet.net p-ISSN: 2395-0072 (2015).

9. UshaVaidehi, P. Factors influencing online shopping behavior of students in engineering colleges at Rangareddy district. Sumedha (2014). 